Acta vet. scand. $1981,22,409-416$.

From the Department of Physiology and the Department of Internal Medicine of Small Animals, Veterinary College of Norway, Oslo.

\title{
PLASMA CONCENTRATIONS OF TESTOSTERONE IN THE MALE DOG AND PLASMA TESTOSTERONE PROFILE FOLLOWING SINGLE INTRAMUSCULAR INJECTION OF HCG*
}

By

A. Sundby and T. Ulstein

SUNDBY, A. and T. ULSTEIN: Plasma concentrations of testosterone in the male dog and plasma testosterone profile following single intramuscular injection of HCG. Acta vet. scand. 1981, 22, 409-416. The spontaneous variation in plasma testosterone was studied in 4 dogs in a $24 \mathrm{~h}$ period. Blood samples were taken with $1 \frac{1 / 2}{h}$ interval. A variation of 26-62\% was found in the plasma testosterone concentration and the values ranged from $2.7-15.6 ; 0.7-10.4 ; 4.2-17.3$; $8.7-23 \mathrm{nmol} / \mathrm{l}$. No effect of intramuscular injection of 150 i.u. HCG could be seen on the plasma testosterone levels in samples taken 5 , 10,20 or $30 \mathrm{~min}$ post injection. Thereafter plasma testosterone levels increased to reach levels equal to peak concentration in the control period $1 \frac{1}{2} \mathrm{~h}$ post injection. The variation in the plasma testosterone concentration $1 \frac{1}{2}, 3$ and $4 \frac{1}{2} \mathrm{~h}$ post $\mathrm{HCG}$ injection was reduced to $8.95 \pm 2.8 \%$ (mean $\pm \mathrm{s}$ ). Plasma testosterone in a sample taken $3 \mathrm{~h}$ after HCG injection might thus be indicative of a Leydig cell dysfunction in the dog. An additional increase $(P<0.001)$ in plasma testasterone levels was observed $21-30 \mathrm{~h}$ post injection. Thereafter levels of testosterone fell to pre-stimulation values.

dog; plasma testosterone; HCG injection.

With a view to using measurement of plasma testosterone as a tool for clinical diagnosis of testicular dysfunction in dogs, it is necessary to study normal plasma testosterone level in this species. Moderate or extensive variation in plasma testosterone concentration during $24 \mathrm{~h}$ periods found in a number of species, including: man (Rowe et al. 1974), monkey (Wilson et al. 1978), rat, mice (Bartke et etl. 1973), rabbit (Rowe et al. 1975, Moor \&

* The investigation was financially supported by the Agricultural Research Council of Norway. 
Younglai 1975), male lamb (Foster et al. 1978), ram (Katongole et al. 1972, Purvis et al. 1974), bull (Katongole et al. 1971, Sanwal et al. 1974, Thibier 1976) and male marsupials (Lincoln 1978), and while this work was in progress, also in dog (DePalatis et al. 1978). HCG stimulation was found to eliminate the extensive variation in plasma testosterone in the bull (Sundby et al. 1975). A purpose of the present investigation was to see whether a similar response occurs in the dog. Testosterone secretion in response to HCG infusion in the spermatic artery in the dog has been extensively studied (Brinck-Johnsen \& Eik-Nes 1957, Eik-Nes 1967). However, the plasma testosterone profile following a single HCG injection and a possible period with steady plasma testosterone concentration has not been investigated previously.

\section{MATERIALS AND METHODS}

Eight adult male dogs were studied. The dogs were raised in a dog kennel (of Dr. N. Koppang), and brought to the Veterinary College a few days before the experiments. In the first experiment 4 dogs ( 3 Labrador and 1 Pointer) were sampled with $1 \frac{1}{2} \mathrm{~h}$ intervals for $24 \mathrm{~h}$. In the second experiment 4 dogs (3 Labrador and 1 English setter) were sampled in a control period ( 7 samples with $1 \frac{1 / 2}{h}$ intervals for each dog). One blood sample was then taken immediately prior to intramuscular injection of 150 i.u. HCG and sampling were continued at 5, 10, 20, 30, 40, 50 and $60 \mathrm{~min}$, then with $1 \frac{1 / 2}{\mathrm{~h}}$ intervals from $1 \frac{1 / 2}{2}-9 \mathrm{~h}$ post injection, then with $3 \mathrm{~h}$ interval from $9-30 \mathrm{~h}$ post injection and additional sampling 48,51 and $125 \mathrm{~h}$ after injection. All samples were taken from cephalic veins using vacutainers (Vacutainer, Becton Dickinson LTD., France). Following centrifugation at $1800 \times \mathrm{g}$ in $10 \mathrm{~min}$ the supernatant plasma was stored at $-20^{\circ} \mathrm{C}$ until analysing. Testosterone was assayed by the radioimmunoassay of Sanwal et al. (1974) as modified by Sundby et al. (1975).

Peripheral plasma HCG levels were measured at Aker Hospital, by Dr. P. Torjesen (Sand \& Torjesen 1973).

\section{RESULTS}

The plasma testosterone profiles in 4 dogs throughout a $24 \mathrm{~h}$ period are shown in Fig. 1. Ranges, mean values, number of 


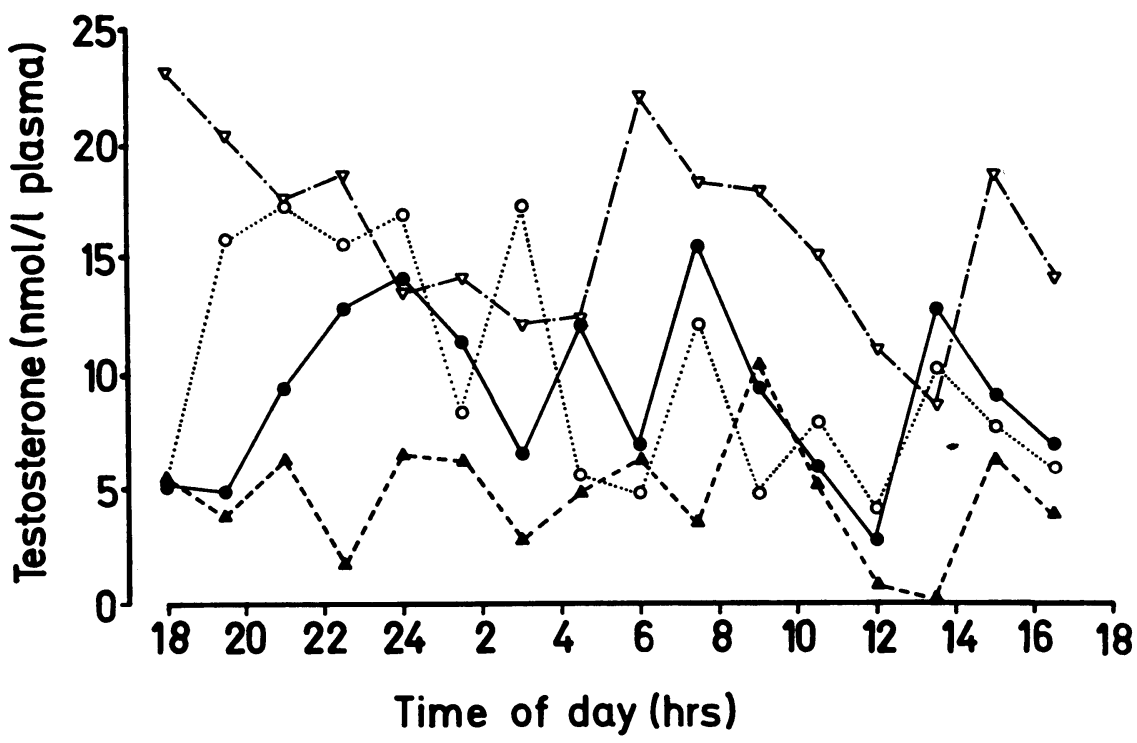

Figure 1. Plasma testosterone profiles in 4 dogs in a $24 \mathrm{~h}$ period.

peaks, peak elevation defined as per cent change from nadir to peak, and time from nadir to peak are listed in Table 1. A moderate fluctuation (26-62\% variation) in plasma testosterone was found. Three dogs had peak values in plasma testosterone around the hour $6-7,13-14$ and $22-23$ of the day. The fourth dog (B) had generally low plasma testosterone concentrations with 5 peaklets during the $24 \mathrm{~h}$ period.

Fig. 2 shows the effect of intramuscular injection of 150 i.u. HCG plasma testosterone levels in 4 dogs. During the control

Ta ble 1. Characteristics of plasma testosterone concentrations in 4 male dogs measured with $1 \frac{1}{2} \mathrm{~h}$ interval in a $24 \mathrm{~h}$ period.

\begin{tabular}{|c|c|c|c|c|c|c|}
\hline \multirow[b]{3}{*}{ Dog } & \multicolumn{3}{|c|}{ Plasma testosterone } & \multirow{3}{*}{$\begin{array}{c}\text { Number } \\
\text { of } \\
\text { peaks }\end{array}$} & \multirow{3}{*}{$\begin{array}{l}\text { Peak } \\
\text { elevation } \\
\text { \%change } \\
\text { from } \\
\text { nadir } \\
\text { to peak }\end{array}$} & \multirow{3}{*}{$\begin{array}{l}\text { Time } \\
\text { from } \\
\text { nadir } \\
\text { to } \\
\text { peak } \\
\text { (min) }\end{array}$} \\
\hline & \multicolumn{2}{|c|}{ nmol/1 } & \multirow{2}{*}{$\frac{\begin{array}{c}\text { variation } \\
\mathrm{s} \times 100\end{array}}{\overline{\mathrm{x}}} \%$} & & & \\
\hline & Range & $\bar{x} \pm s$ & & & & \\
\hline $\mathbf{A}$ & $2.7-15.6$ & $9.4 \pm 3.8$ & 41 & 4 & $64 \pm 14$ & $135 \pm 90$ \\
\hline B & $0.7-10.4$ & $4.5 \pm 2.8$ & 62 & 5 & $65 \pm 19$ & 90 \\
\hline C & $4.2-17.3$ & $10.4 \pm 5.2$ & 50 & 4 & $55 \pm 13$ & $113 \pm 45$ \\
\hline D & $8.7-23$ & $16.3 \pm 4.2$ & 26 & 3 & $50 \pm 6$ & 180 \\
\hline
\end{tabular}






Control period

Time after injection

F i g u r e 2. Plasma testosterone profiles in 4 dogs in a control period and following i.m. injection of 150 i.u. HCG (-). Plasma HCG profiles in the 4 dogs (-.--).

period plasma testosterone fluctuated slightly (14-35\% variance, $n=7$ ). No effect of HCG upon plasma testosterone levels could be seen in samples taken $5,10,20$ or 30 min after injection. In 3 dogs increasing plasma testosterone concentration was observed from $40-60$ min post injection, while in the fourth dog plasma testosterone concentration was kept on a high, slightly fluctuating level. Levels equal to peak concentration in the control period were reached $1 \frac{1}{2} h$ post injection. In these 4 dogs the variation in plasma testosterone levels $1 \frac{1}{2}, 3$ and $4 \frac{1}{2} \mathrm{~h}$ post $\mathrm{HCG}$ injection was $8.95 \pm 2.8 \%$ (mean $\pm \mathrm{s}$ ) compared to a variation of $31 \pm 23 \%$ in the control period at corresponding points in time during the day. A further rise to peak value of 3 times maximal control plasma testosterone concentration was observed $21-30 \mathrm{~h}$ post injection. Thereafter levels of testosterone fell to prestimulation values. The testicular responsiveness to intramuscular injection of 150 i.u. HCG in dogs is thus seen as 
a first increase $(\mathrm{P}<0.001) 1 \frac{1}{2}-6 \mathrm{~h}$ post injection, and an additional increase $(P<0.001) 21-30 \mathrm{~h}$ post injection.

Plasma HCG concentration increased after a single intramuscular injection of 150 i.u. HCG to a level of $45-55$ i.u. HCG/1 $1-3 \mathrm{~h}$ post injection, remained on this level until $10-14 \mathrm{~h}$ post injection. Thereafter plasma HCG concentration fell, and a level of around 10 i.u. HCG/l plasma was measured at the time of maximal plasma testosterone concentration $(21-30 \mathrm{~h}$ post injection). In the period $15-18 \mathrm{~h}$ post injection the fall in $\mathrm{HCG}$ concentration corresponded to a halflife of HCG of about $3 \frac{1}{2} \mathrm{~h}$.

\section{DISCUSSION}

Plasma testosterone was found to fluctuate with $3-5$ peaks (change in elevation from nadir to maximum of $39-88 \%$ ) during a $24 \mathrm{~h}$ period. The plasma testosterone range was in agreement with that reported by DePalatis et al. (1978). However, in the latter investigation 3 dogs were sampled every 20 min and by defining peaks as an elevation from nadir to maximum of at least $25 \%, 10$ to 18 peaks were found in the $24 \mathrm{~h}$ period studied. The variation in plasma testosterone during the day is not sufficiently consistent to make measurement of plasma testosterone in single samples at any fixed time suitable for an evaluation of testicular function. In the bull a single HCG injection was found to reduce the variation in plasma testosterone for a $12 \mathrm{~h}$ period (Sundby et al. 1975) and single sampling at a fixed time following HCG injection was found to be suitable for comparing plasma testosterone between bulls (Sundby \& Velle 1980). In dogs the variation in plasma testosterone following intramuscular administration of 150 i.u. HCG was reduced during a short period only $\left(1 \frac{1}{2}-4 \frac{1}{2} \mathrm{~h}\right.$ post injection). However, plasma testosterone in a sample taken within this period, for instance $3 \mathrm{~h}$ post injection, would be indicative of a testicular malfunction. Whether this level is significantly related to control plasma testosterone concentration, as shown for the bull (Sundby \& Velle 1980) remains to be investigated. No effect of HCG upon plasma testosterone levels in dogs was observed in samples taken $5,10,20$ or 30 min post injection. This is similar to the observation in bulls (Sundby 1981). However, Eik-Nes (1967) and Boyden et al. (1980) found increased testosterone secretion in dogs within 10 min following intravenous infusion 
of HCG into spermatic artery and following a single injection of 25 i.u. HCG into the spermatic vein. A plateau level equal to the peak concentration in the control period reached $1 \frac{1}{2} \mathrm{~h}$ after intramuscular injection is similar to that observed in bulls (Sundby 1981). However, a secondary effect of HCG seen as a further rise in plasma testosterone appeared much earlier post HCG injection in the dog than in the bull, $21-30 \mathrm{~h}$ versus $3-5$ days, respectively (Sundby \& Farahat 1978). The plasma testosterone profile following HCG injection in dogs were on the other hand quite similar to the testicular response to HCG seen in the plasma $5 \alpha$-androstenone and testosterone profiles in pigs ( $A n$ dresen 1975). This might be due to species differences in the halflife of $\mathrm{HCG}$, and in the rate of $\mathrm{HCG}$ induced enzyme synthesis. Peak levels of plasma testosterone occurring at a time when HCG concentration has fallen to very low levels is similar to that reported in the bull (Sundby \& Torjesen 1978).

\section{ACKNOWLEDGEMENTS}

Thanks are due to Dr. N. Koppang for providing the dogs and to K. Nordqvist for help during sampling. The technical assistance of Randi Løes Skogstad is greatly appreciated.

\section{REFERENCES}

Andresen, $\emptyset .: 5 \alpha$-androstenone in peripheral plasma of pigs, diurnal variation in boars, effects of intravenous HCG administration and castration. Acta endocr. (Kbh.) 1975, 78, 385-391.

Bartke, A., R. E. Steele, N. Musto \& B. V. Caldwell: Fluctuations in plasma testosterone levels in adult male rats and mice. Endocrinology $1973,92,1223-1227$.

Boyden, T. W., R. W. Pamenter \& M. A. Silvert: Testosterone secretion by the isolated canine testis after controlled infusions of HCG. J. Reprod. Fertil. 1980, 59, 25-30.

Brinck-Johnsen, T. \& K. B. Eik-Nes: Effect of human chorionic gonadotropin on the secretion of testosterone and 4-androstene-3, 17-dione by the canine testis. Endocrinology 1957, 61, 176-683.

DePalatis, L., J. Moore \& R. E. Falvo: Plasma concentrations of testosterone and LH in the male dog. J. Reprod. Fertil. 1978, 52, 201-207.

Eik-Nes, K. B.: Factors influencing the secretion of testosterone in the anaesthetized dog. Ciba Found. Colloq. Endocrinol. (Proc) 1967, 16, 120-136.

Foster, D. L., I. H. Mickelson, K. D. Ryan, G. A. Coon, R. A. Drongowski \& J. A. Holt: Ontogeny of pulsatile luteinizing hormone and testosterone secretion in male lambs. Endocrinology 1978, 102, 1137-1146. 
Katongole, C. B., F. Naftolin \& R. V. Short: Relationship between blood levels of luteinizing hormone and testosterone in bulls and the effect of sexual stimulation. J. Endocr. 1971, 50, 457466.

Katongole, C. B., R. V. Short \& F. Naftolin: Plasma luteinizing hormone and testosterone in the ram. J. Endocr. 1972, 52, 52-111.

Lincoln, G. A.: Plasma testosterone profiles in male macropodid marsupials. J. Endocr. 1978, 77, 347-351.

Moor, B. C. \& E. V. Younglai: Variations in peripheral levels of LH and testosterone in adult male rabbits. J. Reprod. Fert. 1975, $42,259-266$.

Purvis, K., A. W. Illius \& N. B. Haynes: Plasma testosterone concentrations in the ram. J. Endocr. 1974, 61, 231-253.

Rowe, P. H., C. R. N. Hopkinson, J. C. Shenton \& T. D. Glover: The secretion of $\mathrm{LH}$ and testosterone in the rabbit. Steroids 1975, $25,313-321$.

Rowe, P. H., G. A. Lincoln, P. A. Racey, J. Lehane, M. J. Stephenson, J. C. Shenton \& T. D. Glover: Temporal variations of testosterone levels in the peripheral blood plasma of men. J. Endocr. $1974,61,63-73$.

Sand, T. \& P. A. Torjesen: Dextran-coated charcoal used in the radioimmunoassay of human pituitary luteinizing hormone. Acta endocr. 1973, 73, 444-454.

Sanwal, P. C., A. Sundby \& L. E. Edqvist: Diurnal variation of peripheral plasma levels of testosterone in bulls measured by a rapid radioimmunoassay procedure. Acta vet. scand. 1974, 15, $90-99$.

Sundby, A.: The immediate effect of HCG upon plasma testosterone levels in the bull. Acta vet. scand. 1981, 22, 403-408.

Sundby, A. \& A. Farahat: Plasma testosterone in bulls: Response to various doses of HCG and PMSG. Acta endocr. 1978, 88, 793800.

Sundby, A. \& P. A. Torjesen: Plasma levels of testosterone in bulls: Response to repeated HCG injections. Acta endocr. 1978, 88, 787-792.

Sundby, A. \& W. Velle: Plasma concentration of testosterone in young bulls in relation to age, rate of weight gain and stimulation with human chorionic gonadotropin. J. Endocr. 1980, 86, 465469.

Sundby, A., R. Tollman \& W. Velle: Long-term effect of HCG on plasma testosterone in bulls. J. Reprod. Fertil. 1975, 45, 249—254.

Thibier, M.: Diurnal testosterone and 17 $\alpha$-hydroxyprogesterone in peripheral plasma of young post-pubertal bulls. Acta endocr. 1976, 81, 623-634.

Wilson, M. I., G. M. Brown \& D. Wilson: Annual and diurnal changes in plasma androgen and cortisol in adult male squirrel monkeys (Saimiri sciureus) studied longitudinally. Acta endocr. 1978, 87, 424-434. 


\section{SAMMENDRAG \\ Plasma testosteron konsentrasjoner hos hund og plasma testosteron profil etter en enkel intramuskular HCG injeksjon.}

Variasjonen i plasma testosteron ble studert hos 4 voksne hannhunder $i$ en 24 timers periode. Blodpr $\varnothing v e r$ ble tatt med 11/2 times mellomrom. Plasma testosteron konsentrasjonen svingte mellom 2,716,$6 ; 0,7-10,4 ; 4,2-17,3 ; 8,7-23 \mathrm{nmol} / \mathrm{l}$. Verdiene viste en varians mellom 26-62 \%. Ingen effekt av intramuskulær injeksjon av 150 i.u. HCG kunne påvises i blodprøver tatt 5, 10, 20 eller 30 min etter injeksjonen. Deretter steg nivået av testosteron i plasma og nådde $11 / 2$ time etter HCG injeksjonen et nivå likt toppkonsentrasjonen i kontrollperioden. Variansen $i$ plasma testosteron konsentrasjonen $1 \frac{1}{2}, 3$ og $41 / 2$ time etter time etter HCG injeksjonen var redusert til 8,95 $\pm 2,8 \%$ (gjennomsnitt $\pm s$ ). Plasma testosteron $i$ en prøve 3 timer etter HCG injeksjon vil kunne indikere en dysfunksjon i Leydigcellene hos hund. En ytterligere $\varnothing$ king $(\mathrm{P}<0,001)$ i plasma testosteron nivå ble observert 21-30 timer etter injeksjonen. Deretter falt testosteron nivåt til verdier målt $i$ kontrollperioden.

(Received June 22, 1981).

Reprints may be requested from: A. Sundby, the Department of Physiology, Veterinary College of Norway, P.0. Box 8146, Dep., Oslo 1, Norway. 